EDUKACJA MIĘDZYKULTUROWA

\title{
Uwrażliwianie kulturowe dzieci w praktyce edukacyjnej
}

Streszczenie: W artykule wskazuję na potrzebę uwrażliwiania kulturowego dzieci, jako ważnego aspektu socjalizacji i wychowania oraz ukazuję rolę nauczyciela w tym procesie. W odwołaniu do J. Nikitorowicza koncepcji uwrażliwiania kulturowego oraz A. Bandury teorii społecznego uczenia się przedstawiam wyniki badań własnych przeprowadzonych wśród dzieci w wieku przedszkolnym oraz nauczycieli wychowania przedszkolnego i edukacji wczesnoszkolnej. W opracowaniu podejmuję także próbę odpowiedzi na pytanie, dlaczego warto uwrażliwiać dzieci w wieku przedszkolnym i młodszym wieku szkolnym na różnice kulturowe występujące pomiędzy ludźmi oraz sygnalizuję korzyści, jakie wynikają z takich działań edukacyjnych.

Słowa kluczowe: nauczyciel, dziecko, uwrażliwianie kulturowe, wielokulturowość, edukacja międzykulturowa

\section{Wprowadzenie}

Przemiany społeczno-kulturowe, które można zaobserwować w ciągu ostatnich dwudziestu lat, niosą ze sobą wiele konsekwencji. Szczególnie dostrzegalne jest to w małych społecznościach lokalnych, które pod wpływem zewnętrznych czynników zaczęły się modernizować, rozwijać i zmieniać swoją wewnętrzną strukturę budowaną na bogatej tradycji i obrzędowości. Zmiany widoczne są w sposobie życia, myślenia, w wychowaniu dzieci i w interakcjach społecznych ${ }^{1}$. Sytuacja ta zachęca, ale i wymusza refleksję na temat życia i własnego miejsca w wielokulturowej społeczności.

W Raporcie Międzynarodowej Komisji do spraw Edukacji dla XXI wieku czytamy o czterech filarach edukacji - uczyć się, aby wiedzieć; uczyć się, aby

1 Badania CBOS: Co się zmienito w stylu życia Polaków w ostatnim dwudziestoleciu? Warszawa 2009. http://cbos.pl/SPISKOM.POL/2009/K_019_09.PDF. 
działać; uczyć się, aby być i uczyć się, aby żyć wspólnie². Pierwsze trzy filary dotyczą dostarczania podstawowej wiedzy, ostatni jednak głębszego wymiaru edukacji - stworzenia wspólnego pola oddziaływań i interakcji, opierającego się na poznaniu Innego, dostrzegania współzależności, rozwiązywania konfliktów z poszanowaniem wartości pluralizmu, zrozumienia i pokoju.

Dzieci, szczególnie w wieku przedszkolnym i w młodszym wieku szkolnym, z natury są otwarte na Innych, chętne do poznawania nieznanego i do nawiązywania nowych kontaktów ${ }^{3}$. W Konwencji Narodów Zjednoczonych o Prawach dziecka znajdujemy zapis: „Wszystkie dzieci świata są niewinne, wrażliwe i zależne od dorosłych. Są również ciekawe, aktywne i pełne nadziei [...]"4. Problem nietolerancji tkwi często w mentalności społeczeństwa, w którym dzieci się wychowują, także rodziców i nauczycieli). To, w jaki sposób dzieci postrzegają inne osoby, zależne jest od wzorca, jaki przekazuje im najbliższe otoczenie. Szczególnie ważne zadanie - jak pisze A. Szczurek-Boruta - spoczywa na edukacji, polega ono na przygotowaniu młodego pokolenia do otwartości wobec Innych i ich kultur, przy jednoczesnym zachowaniu własnej tożsamości, autonomii i indywidualizmu ${ }^{5}$.

W niniejszym artykule chciałabym wskazać na potrzebę uwrażliwiania kulturowego dzieci jako ważnego aspektu socjalizacji i wychowania oraz ukazać rolę nauczyciela w tym procesie. W odwołaniu do koncepcji uwrażliwiania kulturowego Jerzego Nikitorowicza oraz teorii społecznego uczenia się Alberta Bandury przedstawię wyniki badań przeprowadzonych wśród dzieci $\mathrm{w}$ wieku przedszkolnym oraz nauczycieli wychowania przedszkolnego i edukacji wczesnoszkolnej.

Na podstawie literatury przedmiotu, wyników badań ilościowych i jakościowych formułuję tezę, że większość nauczycieli nie prowadzi działań mających na celu uwrażliwianie kulturowe dzieci. Uwrażliwianie kulturowe postrzegam jako doskonalenie kompetencji społecznych, uczenie szacunku

2 J. Delors: Edukacja. Jest w niej ukryty skarb. Raport dla UNESCO. Warszawa 1998, Wydawnictwo Stowarzyszenie Oświatowców Polskich, s. 9.

3 Szerzej na ten temat np.: M. Przetacznik-Gierowska, G. Makiełło-Jarża: Psychologia rozwojowa $i$ wychowawcza wieku dziecięcego. Warszawa 1992, WSiP.

4 Podaję za: R. Schaffer: Psychologia dziecka. Warszawa 2014, PWN, s. 44.

5 A. Szczurek-Boruta: Tożsamość $i$ jej szerszy kontekst instytucjonalny - o przydatności teorii strukturalizacji Anthony'ego Giddensa dla teorii i praktyki edukacji międzykulturowej. W: T. Lewowicki, A Szczurek-Boruta, E. Ogrodzka-Mazur: Teorie i modele badań międzykulturowych. Cieszyn - Warszawa 2006, UŚ, Wyższa Szkoła Pedagogiczna ZNP w Warszawie, s. 37. 
i tolerancji do Innego/drugiego człowieka, wskazywanie różnic, ale przede wszystkim podobieństw występujących pomiędzy ludźmi, a także rozwijanie umiejętności współpracy i rozwiązywania konfliktów na drodze dialogu.

\section{Założenia teoretyczno-metodologiczne badań własnych}

Osoby, które zajmują się kształceniem i wychowaniem młodych pokoleń, systematycznie powinny poszerzać swoje kompetencje i stale pracować nad sobą. Szczególnie istotne jest to $\mathrm{w}$ pracy z małymi dziećmi, gdyż potencjalnie ta grupa nauczycieli ma możliwość największego oddziaływania na proces kształtowania się tożsamości dziecka ${ }^{6}$.

W obliczu zmian dokonujących się we współczesnych społeczeństwach pedagodzy mają bardzo trudne zadanie, jakim jest ukształtowanie świadomości wychowanka w taki sposób, aby samodzielnie potrafił wybierać wartości, respektować je i przyjmować odpowiedzialność za ich realizację. Teza K. Olbrycht sformułowana pod koniec XX wieku, mówiąca o kryzysie wartości, jest nadal aktualna. W tym kontekście szczególnie ważne staje się więc wychowanie ku wartościowemu życiu, uwrażliwianie na wartości ogólnoludzkie i uniwersalne, uczenie tolerancji ${ }^{8}$.

Mądre wychowanie, inaczej wychowanie do człowieczeństwa, to zdaniem W. Papugowej: „przekazanie dziecku podstawowych umiejętności społecznych, które pozwolą mu na przystosowanie się do życia w grupie, budowanie bezpiecznych relacji bliskości i empatyzowanie" 9 . Wychowanie to nie tylko uczenie zasad, norm, ale przede wszystkim uwrażliwianie na drugiego człowieka.

W dobie powszechnej wielokulturowości nauczyciel powinien zdawać sobie sprawę, jak istotne jest przygotowanie dzieci do życia w szacunku i akceptacji, mimo różnic i odmienności. Katarzyna Olbrycht w koncepcji kształcenia aksjologicznego znaczącą rolę w akceptowaniu odmienności przypisuje systemowi wartości, uważając tym samym, że szacunek do drugiego czło-

6 Szerzej na ten temat: M. R. Radwiłowiczowie: Nauczyciel klas poczatkowych. Warszawa1981, WSiP.

7 Por. Koncepcja kształcenia aksjologicznego Katarzyny Olbrycht. Szerzej na ten temat: K. Olbrycht: Prawda, dobro, piękno w wychowaniu człowieka. Katowice 2000, UŚ.

8 K. Olbrycht: Tolerancja a wychowanie. W: K. Olbrycht (red.): Edukacja aksjologiczna. Katowice 1995, UŚ.

9 W. Papugowa: Jak wychowujemy? „Bliżej Przedszkola” 2015, nr 11, s. 24. 
wieka wymaga spojrzenia poprzez pryzmat tego, co uważa za ważne i cenne $^{10}$. Dzieci powinny nauczyć się empatycznego spojrzenia na Innych. Od najmłodszych lat warto uświadamiać im fakt, że nie wszyscy muszą być tacy sami. Niwelowanie postawy egocentryzmu, a tym samym uczenie dialogu i tolerancji, jest nadzieją na ograniczenie konfliktów i nieporozumień w wielokulturowym społeczeństwie w przyszłości.

W praktyce szkolnej wychowanie do wartości - uczenie szacunku, tolerancji i współpracy - można przypisać założeniom programu uwrażliwiania kulturowego opracowanego przez J. Nikitorowicza ${ }^{11}$. Uświadamianie różnic, ale przede wszystkim podobieństw pomiędzy ludźmi, stanowi najważniejszy aspekt uwrażliwiania. Wielowymiarowość Innego/drugiego człowieka - różniącego się ze względu np. na płeć, wiek, wyznanie, status materialny (biedny, bogaty), niepełnosprawność, narodowość, rasę, etnicznośćc ${ }^{2}$ - na którą zwraca uwagę A. Szczurek-Boruta, pozwala nam, pomimo różnic kulturowych, szukać wspólnych cech z Innymi, a przez to lepiej poznać siebie.

Zdaniem J. Nikitorowicza świadomość inności przekształca się w obcość dopiero wtedy, gdy pojawiają się emocje i postawy łączące się z pojawiającą różnicą, wzbudzającą lęk, strach i agresję. Edukacja ma zatem kształtować stosunek do Innych ${ }^{13}$, zapobiegać stereotypom, uprzedzeniom i wrogości. J. Nikitorowicz wskazuje istotę uwrażliwiania dzieci na potrzeby Innych oraz porozumienia na drodze dialogu i zrozumienia. Podkreśla, że niewiedza jest często powodem obaw, wycofania i marginalizowania. Wczesne uwrażliwianie dzieci na różnice występujące pomiędzy ludźmi jest szansą na to, że w przyszłości nie będą się obawiały Innych, a przeciwnie - być może staną

10 K. Olbrycht: Rola kształcenia aksjologicznego w działaniach pedagogicznych w społecznościach wielokulturowych. W: T. Lewowicki, E. Ogrodzka-Mazur, A. Gajdzica (red.): Świat wartości i edukacja międzykulturowa. Cieszyn - Warszawa 2003, UŚ, Wyższa Szkoła Pedagogiczna ZNP w Warszawie, s. 218.

11 Szerzej na ten temat: J. Nikitorowicz: Edukacja międzykulturowa. Kreowanie tożsamości dziecka. Gdańsk 2008, GWP J. Nikitorowicz: Tolerancja. Idea i cel edukacji międzykulturowej. „Problemy Opiekuńczo-Wychowawcze” 1995, nr 6; J. Nikitorowicz: Wielokulturowość - wyzwania dla edukacji międzykulturowej. W: J. Gajda (red.): Edukacja zorientowana na XXI w. Lublin 2000, UMCS.

12 A. Szczurek-Boruta: Doświadczenia społeczne w przygotowaniu przyszłych nauczycieli do pracy w warunkach wielokulturowości. Toruń 2013, Wydawnictwo Adam Marszałek, s. 134-142.

13 J. Nikitorowicz: Edukacja międzykulturowa. Kreowanie tożsamości dziecka. cyt. wyd., s. 108. 
się otwarte, a różnice będą postrzegały jako zaletę, a nie wadę. Dlatego też ważne z punktu widzenia tej koncepcji jest dostarczanie dzieciom wiedzy na temat Innego/drugiego człowieka, wskazywanie jego potrzeb i uświadamianie wartości, jaką jest inność. Uwrażliwianie ma wzbudzić ciekawość i chęć poznania. Jak twierdzi J. Nikitorowicz: „Drugi - Inny jest nam niezbędny, aby odkrywać na nowo siebie i umożliwiać patrzenie z perspektywy, z jego okna, jego podwórza, jego oczyma"14.

Liczne badania z zakresu pedagogiki i psychologii rozwojowej potwierdzają fakt, że dzieci najszybciej uczą się poprzez naśladownictwo. A. Bandura, twórca teorii społecznego uczenia się ${ }^{15}$, zwraca uwagę na mechanizm nauki poprzez odwzorowywanie zachowania i postaw innych ludzi ${ }^{16}$. Prowadzone przez niego eksperymenty dowodzą, że dzieci przechowują w pamięci zachowania modela (osób znaczących), a także dokładnie je powielają. Zdaniem psychologa czynniki warunkujące te zachowania widoczne są w różnych rodzajach modelowania - począwszy od naśladowania pojedynczych czynności, po złożone zachowania społeczne ${ }^{17}$. Dziecko, przebywając w grupie, naśladuje zachowania rówieśników, ale przede wszystkim nauczyciela, którego uważa za swój autorytet i wzór.

Dzieci uczą się w działaniu, gromadząc doświadczenia, co bezpośrednio wiąże koncepcję J. Nikitorowicza z teorią społecznego uczenia się A. Bandury. J. Nikitorowicz podkreśla, że nabywanie umiejętności dialogu i uczenie się kompetencji społecznych odbywa się wtedy, gdy jednostka jest aktywna.

Zamysłem podjętych poczynań badawczych było ustalenie, czy nauczyciele wychowania przedszkolnego i edukacji wczesnoszkolnej uwrażliwiają dzieci na różnice występujące pomiędzy ludźmi (w wyglądzie zewnętrznym, zachowaniu), czy uświadamiają im istnienie równolegle innych kultur, a tym samym tradycji, zwyczajów różniących się od ich własnych.

Badania prowadzone były od września w latach 2014-2015 w trzech zespołach szkolno-przedszkolnych w województwie śląskim. Teren badań

\footnotetext{
14 Tamże, s. 120.

15 Szerzej na ten temat: A. Bandura: Teoria społecznego uczenia się. Warszawa 2007, PWN.

16 K.-J. Tillmann: Teorie socjalizacji. Społeczność, instytucja, upodmiotowienie. Warszawa 1996, PWN, s. 80-82.

17 A. Birch: Psychologia rozwojowa w zarysie. Od niemowlęctwa do dorostości. Warszawa 2012, PWN, s. 151-152.
} 
wybrany został celowo ze względu na zróżnicowanie kulturowe występujące na tym obszarze ${ }^{18}$, coraz częściej pojawiających się imigrantów oraz wielość wyznań (ludność wyznania katolickiego, ewangelicko-augsburskiego, osoby należące do zborów zielonoświątkowców).

Warto zaznaczyć, że wybrany obszar badań wpisuje się w Bachtinowską koncepcję pogranicza kultur. Idea „pogranicza kultur” Michaiła Bachtina dotyczy postrzegania kultury jako całości, której granice się przenikają ${ }^{19}$ i pomimo wspólnego terytorium, języka i kultury obszar ten stanowi pogranicze. Jak twierdzi J. Nikitorowicz: „Życie na skrzyżowaniu kultur pozwala wykraczać myślowo poza obszar uwarunkowany osiadłością, gdyż usytuowanie terytorialne uruchamia skale porównawcze, które działają jako bodźce"20.

Grupa badana liczyła 102 osoby $^{21}$, w tym 52 nauczycieli i 50 dzieci. W badaniach wzięli udział nauczyciele edukacji wczesnoszkolnej i wychowania przedszkolnego pracujący w grupach, do których uczęszczały dzieci różniące się rasowo, etnicznie, wyznaniowo (kobiety w wieku od 25-54 lat; nauczyciele kontraktowi - 11 osób, mianowani - 21 osób i dyplomowani 20 osób; staż pracy do 2 do 33 lat). Obserwacje wśród dzieci prowadzone były w dwóch grupach przedszkolnych (50 dzieci - 4-5-letnie).

W badaniach zastosowałam triangulację metod jakościowych i ilościowych, które uważam za komplementarne względem siebie. Zdaniem S. Palki „wykorzystanie obu strategii badawczych [...] stwarza większe szanse pełniejszego poznania, eliminowania błędów poznawczych, niż stosowanie tylko jednej metody $[\ldots]^{\prime 22}$.

Wykorzystano metodę sondażu diagnostycznego, stosowaną w metodologii badań ilościowych (badanie kwestionariuszem ankiety przeprowadzone wśród nauczycieli), metody badań jakościowych: wywiady fokusowe, inaczej

18 Szerzej na ten temat: http://www.slaskie.pl/

19 Por. m.in. M. Bachtin: Problemy literatury i estetyki. Warszawa 1992, Czytelnik; L. Witkowski: Uniwersalizm pogranicza: o semiotyce kultury Michaiła Bachtina w kontekście edukacji. Toruń 1991, Wydawnictwo Adam Marszałek.

20 J. Nikitorowicz: Pogranicze. Tożsamość. Edukacja międzykulturowa. Białystok 1995, Wydawnictwo Uniwersyteckie „Trans Humana”, s. 14.

21 Zdaniem M. Łobockiego grupa badana licząca powyżej 100 osób stanowi próbę dużą. M. Łobocki: Wprowadzenie do metodologii badań pedagogicznych. Karków 1992, Oficyna Wydawnicza „Impuls”, s. 172.

22 S. Palka: Triangulacja w badaniach procesu dydaktyczno-wychowawczego. http://repozytorium.ukw.edu.pl (18.11.2015) oraz S. Palka: Metodologia. Badania. Praktyka pedagogiczna. Gdańsk 2006, GWP. 
zogniskowane (przeprowadzone z nauczycielami), obserwacje etnograficzne $\mathrm{w}$ grupach przedszkolnych ${ }^{23}$ oraz wywiady indywidulane $\mathrm{z}$ chętnymi dziećmi.

\section{Uwrażliwianie kulturowe dziecka w praktyce edukacyjnej - prezentacja wyników badań}

Zachowanie odpowiedniej procedury badawczej oraz wykorzystanie prawidłowo dobranych metod badań pozwoliło na uzyskanie rzetelnych wyników i tym samym przeanalizowanie podejścia nauczycieli do kwestii uwrażliwiania kulturowego dzieci oraz wyciągnięcia odpowiednich wniosków dotyczących praktyki edukacyjnej w tym zakresie.

Badania wśród dzieci potwierdziły postawioną tezę, dotyczącą tego, że pedagodzy nie prowadzą działań mających na celu uwrażliwianie kulturowe dzieci, a jeżeli już ma to miejsce, to są to działania sporadyczne i ukierunkowane głównie na tematykę związaną ze starością.

Prowadzone obserwacje etnograficzne dowodzą, że dzieci w bardzo dużym stopniu odwzorowują (A. Bandura w swojej teorii mówi o naśladowaniu zachowań modela - w tym przypadku modelem jest nauczyciel) zachowania nauczycieli, co jest istotne w przypadku prowadzonych rozważań dotyczących uwrażliwiania kulturowego. Obserwacje trwały trzy miesiące i miały charakter ukryty ${ }^{24}$, co pozwoliło na zaobserwowanie wielu sytuacji świadczących o tym, że stosunek nauczyciela do osób z personelu, rodziców, ale i samych wychowanków naśladowany jest przez dzieci. Obserwacji podlegały czynności nauczyciela, tj. np. rozmowy z wychowankami, sposoby rozwiązywania konfliktów oraz ich interpretacja i naśladowanie przez dzieci. W pierwszej grupie nauczyciel uśmiechał się bardzo rzadko, na wiele sytuacji reagował krzykiem - dzieci w tej grupie były agresywne i często popadały w konflikty. W drugiej grupie - gdzie nauczyciel przejawiał pozytywne emocje: był życzliwy i często się uśmiechał - dzieci były radosne i bardzo rzadko

23 Klasyfikacja metod badawczych w ujęciu Krzysztofa Rubachy. K. Rubacha: Metodologia badań nad edukacją. Warszawa 2008, WAiP, s. 132.

24 Zastosowano obserwację etnograficzną ukrytą, aby uniknąć ewentualnej modyfikacji zachowań osób obserwowanych. Obserwacja była prowadzona w sposób ciągły i miała charakter całościowy. Główne aspekty obserwacji: zachowanie nauczyciela, sposób komunikacji z uczniami, uwrażliwianie kulturowe dzieci - uświadamianie różnic, podobieństw występujących pomiędzy ludźmi itp. Szerzej na temat obserwacji, jako metody w badaniach pedagogicznych: K. Rubacha: Metodologia badań nad edukacja. cyt. wyd., s. 151-156. 
zaobserwować można było sprzeczki pomiędzy nimi. Sytuacje te świadczą o bezpośrednim oddziaływaniu zachowania nauczyciela na zachowania dzieci i relacje w grupie.

Zauważyć też można było, że dzieci naśladują również pewne czynności świadomie, a także potrafią odtworzyć je w określonych sytuacjach. W grupie pierwszej nauczyciel po przyjściu każdego dziecka do sali witał się z nim przez podanie ręki. Obserwując zachowanie dzieci, zauważyć można było, że one także witają się podobnie ze swoimi kolegami, kiedy przychodzą do sali. Przytoczone sytuacje, ale i wiele innych, tj. np. naśladowanie mimiki twarzy, odwzorowywanie sposobów rozwiązywania konfliktów, a także używanie podobnych słów, potwierdzają założenia teorii A. Bandury. Dzieci naśladowały pojedyncze czynności, tj. uśmiechanie się, głaskanie dzieci z grupy, ale też złożone stereotypie ruchowe, np. witanie się z innymi za pomocą podania ręki.

Po obserwacjach nasuwa się wiele wniosków, jednak najważniejszy dotyczy tego, że dzieci modelują zachowania nauczycieli, zarówno pozytywne (np. głaskanie, uśmiechanie się), jak i negatywne (np. sadzanie dzieci na krzesełko w przypadku nieposłuszeństwa). Wszystkie zachowania nauczyciela implikują zachowania dzieci, które z czasem są coraz bardziej świadome, a przede wszystkim przekładają się na współżycie w grupie rówieśniczej. W związku z tym istotnie ważne jest, aby nauczyciel nie tylko tłumaczył i wychowywał, ale przede wszystkim uczył w działaniu, poprzez stwarzanie odpowiedniej atmosfery pomiędzy dziećmi w grupie i nakłanianie do dialogu. Istotne jest, aby nauczyciel uświadomił sobie, że sposób zachowania się dzieci w stosunku do swoich rówieśników, ale także innych osób, w dużej mierze zależy od niego.

Uwrażliwianie kulturowe jest różnie postrzegane przez badanych nauczycieli. Pomimo powszechnej wielokulturowości i zróżnicowania kulturowego grupy, w której pracują, wciąż wielu nauczycieli nie widzi potrzeby uwrażliwiania swoich wychowanków na różnice kulturowe występujące pomiędzy ludźmi. Powyższe kwestie ilustruje wykres 1 . W grupie 52 ankietowanych nauczycieli tylko 22 uważa, że uwrażliwianie dzieci jest istotne i potrzebne. Zdecydowana większość, bo aż 30 osób, twierdzi, że nie uwrażliwia dzieci na różnice występujące pomiędzy ludźmi (udzielone odpowiedzi - nie, raczej nie, zdecydowanie nie).

Zdania dotyczące konieczności prowadzenia działań w zakresie uwrażliwiania kulturowego dzieci wśród badanych nauczycieli były podzielone. Część z nich zdecydowanie twierdziła, że jest to potrzebne (uświadamianie jest istotne, uczy współżycia z innymi ludźmi, jest to uczenie szacunku, tolerancji), kwestie te obrazuje przytoczona wypowiedź: 
Ważne jest uświadamianie dzieciom różnic występujących pomiędzy ludźmi. Szczególnie jest to potrzebne wtedy, gdy w najbliższym otoczeniu dziecka znajdują się osoby odmienne kulturowo, innego wyznania lub rasy. Dzieci są spostrzegawcze i powinno im się od początku tłumaczyć, dlaczego mimo różnic wszyscy zasługujemy na szacunek i tolerancję.

(kobieta, nauczycielka zintegrowanej edukacji wczesnoszkolnej, nauczycielka kontraktowa, 4 lata stażu pracy).

Zdecydowana większość badanych była jednak zdania, że nie powinno się tego robić (powodem jest - młody wiek dzieci, ograniczone kompetencje, niski poziom wiedzy na ten temat). Przykładowe wypowiedzi nauczycieli ${ }^{25}$ przytoczone zostały poniżej:

Wykres 1. Deklaracje badanych nauczycieli dotyczące tego, czy uwrażliwiają swoich wychowanków na różnice kulturowe występujące między ludźmi

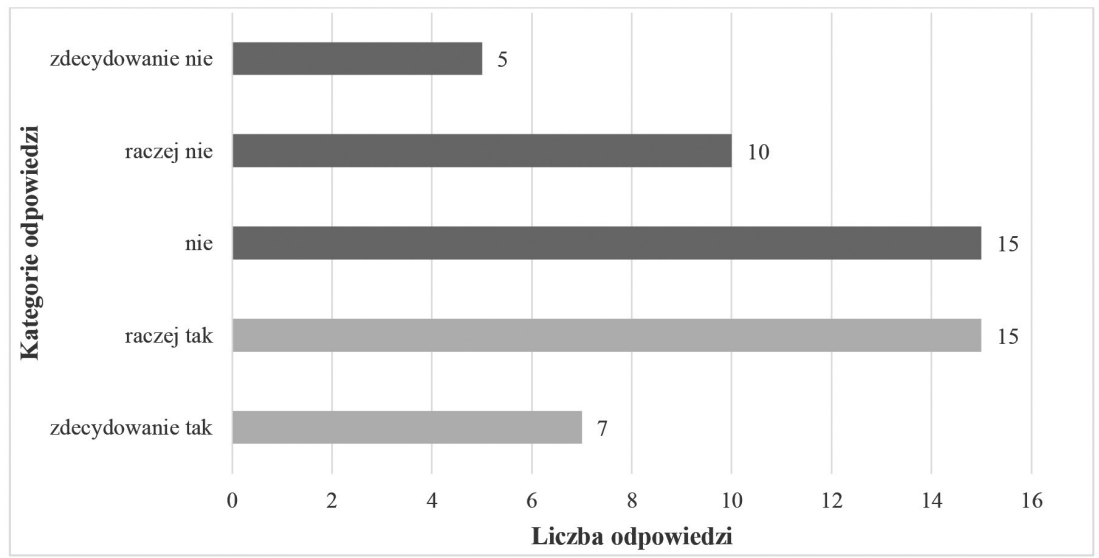

Źródło: badania własne.

25 Przytoczone wypowiedzi pochodzą z wywiadów fokusowych przeprowadzonych z nauczycielami wychowania przedszkolnego i edukacji wczesnoszkolnej. Wywiady przeprowadzone były w dwóch grupach, po 7 nauczycieli. Dotyczyły kwestii uwrażliwiania kulturowego dzieci, stosowanych metod pracy oraz tego czy praca nauczyciela w grupie zróżnicowanej kulturowo jest wyzwaniem czy problemem. Każdy wywiad trwał ok. 20 min, prowadzony był przez moderatora, a jego przebieg był nagrywany. Szerzej na temat wywiadów fokusowych: M. Guzik-Tkacz: Badania diagnostyczne w pedagogice i w psychopedagogice. Warszawa 2011, Wydawnictwo Akademickie „Żak”. 
Moim zdaniem wszystko zależy od wieku wychowanków. Dzieci w wieku przedszkolnym są za małe, żeby tłumaczyć im np. dlaczego ktoś ma inny kolor skóry czy dlaczego jest innego wyznania.

(kobieta, wychowawczyni w przedszkolu, nauczycielka mianowana, 10 lat stażu pracy).

Uwrażliwianie kulturowe powinno być prowadzone przez specjalistów.

Nie czuję się na tyle kompetentna, żeby prowadzić takie zajęcia.

(kobieta, wychowawczyni w przedszkolu, nauczycielka dyplomowana, 26 lat stażu pracy).

Wypowiedzi respondentów jednoznacznie wskazują, że część nauczycieli nie jest świadoma tego, czego dotyczy uwrażliwianie, i jak bardzo jest ono związane z socjalizacją i uspołecznianiem dziecka. Szczególnie w grupach, w których dziecko na co dzień spotyka się z kolegami z innych grup etnicznych.

Podczas obserwacji w grupach przedszkolnych bardzo rażąca była kwestia dotycząca traktowania dzieci innego wyznania w grupie większości rzymskokatolickiej. W przedszkolach, w których były prowadzone badania, odbywały się tylko zajęcia z religii dla dzieci wyznania rzymskokatolickiego. Rodzice pozostałych dzieci mieli prawo zdecydować, czy ich dziecko będzie uczęszczało na religię, czy też nie. W czasie religii dzieci, które nie miały zgody rodziców na uczestnictwo w zajęciach, przechodziły z wychowawcą do innej sali. Większość z nich nie była świadoma dlaczego. W trakcie obserwacji tylko raz jedna z nauczycielek tłumaczyła dziecku:

Ty chodzisz do innego kościółka niż reszta twoich kolegów, dlatego idziesz ze mną do innej sali.

(kobieta, nauczycielka mianowana).

Inny problem, jaki zauważyłam podczas obserwacji, dotyczył lekceważenia przez nauczycieli wychowanków. Szczególnie w sytuacji, kiedy dzieci dostrzegały różnice w wyglądzie swoim i swoich kolegów (jedna dziewczynka była innej rasy niż pozostała część grupy), a nauczyciel nie starał się wyjaśnić, dlaczego one występują i czym są uwarunkowane. Zachowanie nauczyciela powodowało tym samym samodzielnie ukierunkowanie myślenia dzieci.

Nasza koleżanka jest brudna, chyba się nie umyła.

(dziecko 1)

Nie będę się z nią bawiła, bo jeszcze się czymś zarażę. (dziecko 2) 
Przywołane wypowiedzi dzieci są wynikiem ignorowanie przez nauczycieli istniejących problemów, a także wskazują na niewiedzę nauczycieli w zakresie uwrażliwiania dzieci, niskie kompetencje międzykulturowe, ale też co najgorsze, że środowiska zróżnicowane kulturowo nadal traktują kulturę większości jako tę dominującą.

Dzieci uczestniczące w badaniu, w indywidualnych wywiadach, wskazywały, że chciałaby, aby wszyscy wyglądali tak samo. Nie traktują różnicy w kategorii czegoś pozytywnego, tylko różniącego, a w skrajnych przypadkach nawet negatywnego. „Inny” kolega jest przez nich często odtrącany w zabawie lub podczas zajęć. Wynika to często z ich niewiedzy, ale także obawy przed nieznanym.

Nauczyciele biorący udział w badaniu różnie rozumieją, czym jest zróżnicowanie kulturowe, poniżej przytaczam kilka wypowiedzi udzielonych przez nauczycieli w kwestionariuszu ankiety.

Zróżnicowanie kulturowe to różnice tj. kolor skóry, wyznanie.

Przede wszystkim inny język, kolor skóry.

Różnice dotyczące kultury, tradycji, zwyczajów, inny wygląd, kolor skóry.

Ludzie różnych narodowości.

Współżycie lub współwystępowanie ludzi zamieszkujących dane terytorium, różniących się względem siebie językiem, wyznawaną religią, poglądami, obyczajami.

Wypowiedzi nauczycieli świadczą o tym, że zróżnicowanie kulturowe postrzegają przede wszystkim jako różnice w kolorze skóry i odmiennej narodowości (język, tradycje, zwyczaje). Zaledwie 5 nauczycieli w grupie 52 respondentów wspomina o różnicach wyznaniowych. Nauczyciele nie wskazali, że różnicą kulturową może być płeć.

Sposoby postrzegania zróżnicowania kulturowego przez nauczycieli mogą być przyczyną tego, że nie czują potrzeby uwrażliwiania kulturowego dzieci - nie traktują płci, wyznania i niepełnosprawności jako różnicy kulturowej.

W polskim systemie oświaty treści dotyczące uwrażliwiania kulturowego (szerzej edukacji międzykulturowej) określa Rozporządzenie Ministra Edukacji Narodowej z dnia 27 sierpnia 2012 roku $^{26} \mathrm{~W}$ sprawie podstawy programo-

26 Rozporzadzenie Ministra Edukacji Narodowej z dnia 27sierpnia 2012 r. w sprawie podstawy programowej wychowania przedszkolnego oraz kształcenia w poszczególnych typach szkót. http://isap.sejm.gov.pl (20.11.2015). 
wej wychowania przedszkolnego oraz kształcenia w poszczególnych typach szkół. Na etapie wychowania przedszkolnego i edukacji wczesnoszkolnej znajdują się wśród nich np. „szacunek dla innych ludzi”, „tolerancja wobec innej narodowości”, a na etapie wychowania przedszkolnego - „współpraca z innymi w zabawie, [...] przestrzeganie reguł w społeczności dziecięcej oraz świecie dorosłych". W dużej mierze realizacja tych treści wyznaczona jest kreatywnością, inwencją i postawą nauczyciela ${ }^{27}$.

Przekazywanie treści z zakresu edukacji międzykulturowej wymaga od samego nauczyciela: wrażliwości, świadomości procesów społecznych i odczuwania potrzeby dialogu międzykulturowego ${ }^{28}$. Ponadto w pracy nauczyciela, zdaniem A. Szczurek-Boruty, istotna jest umiejętność uczenia się od Innych i konstruowania wiedzy swojej i swojego ucznia w różnych kontekstach ${ }^{29}$. Nauczyciel powinien szukać różnych metod pracy i rozwiązań, które nie tylko zainteresują dziecko, ale będą też efektywne.

J. Nikitorowicz podkreśla, jak istotną rolę w kształtowaniu tożsamości dziecka odgrywa oswajanie z samym sobą i innością, czego w wynikach badań nie dostrzeżono. W „Programie uwrażliwiania kulturowego” zwraca szczególną rolę na uczenie dziecka postrzegania Innego w kategorii interesującego przezwyciężenia myślenia schematycznego, w którym Inni to Obcy. Choć program skierowany jest do dzieci od 6 roku życia, nie stanowi to przeszkody, aby założenia i idee przekazywać już małym dzieciom, szczególnie, że Podstawa programowa wychowania przedszkolnego i edukacji wczesnoszkolnej jest spójna z założeniami tego programu.

Główne zadania „Programu uwrażliwiania kulturowego” są następujące:

- kształtowanie międzykulturowego i międzyludzkiego dialogu;

- wzmacnianie własnej tożsamości rodzinnej, lokalnej;

- na pierwszym miejscu stoi człowiek w oparciu o rdzenne wartości;

- rozwijanie zdolności interakcji i komunikacji dzieci z najbliższym otoczeniem, a na jego bazie z dalszym światem;

- aktywizacja uczniów;

- współdziałanie na zasadzie uzyskiwania kompromisu i negocjacji ${ }^{30}$.

27 B. Dobrowolska: Postawy nauczycieli wobec edukacji międzykulturowej a kultura szkoty. Kraków 2015, Oficyna Wydawnicza „Impuls”, s. 40.

28 Tamże, s. 40-44.

29 A. Szczurek-Boruta: O przygotowaniu nauczycieli do pracy w warunkach wielokulturowości - konteksty, opinie studentów, propozycje. cyt. wyd., s. 27.

30 Na podstawie: J. Nikitorowicz: Edukacja międzykulturowa. Kreowanie tożsamości dziecka. cyt. wyd., s. 104-199. 
Program dotyczy uwrażliwiania dziecka na inność/obcość w wymiarze biologicznym, społecznym, ale też kulturowym.

Nauczyciele - 36 osób z badanej grupy, zauważają w programach nauczania treści uwrażliwiania kulturowego dzieci - dotyczą one przede wszystkim osób starszych, niepełnosprawnych, rzadko pojawiają się kwestie związane $\mathrm{z}$ różnicami, tj. rasa, wyznanie. Zapytani jednak o to, w jaki sposób odnoszą się do tych kwestii w swojej codziennej pracy, odpowiadali, że są to raczej zajęcia tematyczne związane np. z Dniem Babci i Dziadka (osoby starsze) czy świętami. Żaden z biorących w badaniu nauczycieli nie zdeklarował, że wychodzi naprzeciw zainteresowaniom dzieci czy też prowadzi zajęcia cykliczne związane np. z poznawaniem tradycji dzieci odmiennych kulturowo uczęszczających do grupy.

Praca pedagoga wymaga od niego wiedzy, akceptacji różnych poglądów, a przede wszystkim skutecznego przeciwstawiania się stereotypom - rodziców, uczniów, innych nauczycieli. W wywiadach fokusowych zapytałam nauczycieli o to, czy ich zadaniem praca w grupie, w której występują różnice kulturowe pomiędzy dziećmi, jest wyzwaniem czy problemem. Zdania na ten temat były podzielone. Poniżej przytaczam kilka wypowiedzi:

Praca w takiej grupie jest, moim zdaniem, wyzwaniem dla nauczyciela. Każde z tych dzieci powinno być uczone według programu, a jednak trzeba zajęcia z nimi prowadzić tak, aby uwzględnić ich różnice kulturowe. [...] I to jest właśnie wyzwanie dla nauczyciela.

(wywiad fokusowy nr 1, kobieta, nauczycielka kontraktowa, wychowawczyni w przedszkolu, staż pracy 5 lat).

Zdecydowanie wyzwaniem, ponieważ podczas organizowania procesu dydaktycznego trzeba tak konstruować treści i narzędzia by były one dostosowane do danej grupy, zrozumiałe i nie godziły czy o,brażały danego kręgu kulturowego [...]

(wywiad fokusowy nr 2, nauczycielka mianowana, nauczycielka edukacji wczesnoszkolnej, staż pracy 10 lat).

Wydaje mi się, że jest to problem. Programy nauczania są przeładowane, nie ma czasu na realizowanie dodatkowych tematów. Ważniejsze w moim odczuciu jest skupianie się na obowiązkowych treściach z edukacji polonistycznej czy matematycznej [...]

(wywiad fokusowy nr 2, nauczycielka dyplomowana edukacji wczesnoszkolnej, staż pracy 25 lat). 
W obliczu reform i szybkich zmian w prawie oświatowym sprawy uwrażliwiania kulturowego dzieci są problemem. Nawet w grupie zróżnicowanej kulturowo wystarczy realizować program nauczania, przecież jest napisany w oparciu o podstawę

(wywiad fokusowy nr 1, nauczycielka dyplomowana wychowania przedszkolnego, staż pracy 20 lat).

Na podstawie przytoczonych wypowiedzi można stwierdzić, że część nauczycieli nie jest świadoma tego, jak ważne jest uwrażliwianie kulturowe dzieci. Nauczyciele biorący udział w badaniach, mimo tego, że pracują w grupach, w których dzieci są zróżnicowane płciowo, wyznaniowo, ale i narodowościowo, nie włączają do kształcenia treści, które miałyby na celu pomóc im zrozumieć różnice występujące pomiędzy rówieśnikami w najbliższym otoczeniu. Stosunek nauczycieli do kwestii uwrażliwiania przekłada się na relacje pomiędzy dziećmi w grupie. Nadal wielu nauczycieli uważa, że praca w warunkach wielokulturowości jest problemem. Ważne jest jednak to, aby nauczyciele pomimo pojawiających się trudności i obaw wychodzili naprzeciw oczekiwaniom dzieci i oprócz obowiązkowej realizacji programu, co podkreślali w swoich wypowiedziach, zwracali uwagę na treści równie istotne, jak edukacja polonistyczna czy matematyczna - a mianowicie wychowanie do człowieczeństwa, uczenie szacunku i tolerancji.

\section{Konkluzje}

Zarysowane w tym opracowaniu kwestie zmuszają do refleksji. Szczególnie istotne wydaje się zwrócenie uwagi na podejście współczesnych nauczycieli do uwrażliwiania kulturowego dzieci. Interpretując wypowiedzi nauczycieli oraz wyniki przeprowadzonych obserwacji zauważam, że młodzi nauczyciele (kontraktowi) są bardziej otwarci, świadomi odpowiedzialności, ale też korzyści, jakie niesie z sobą uwrażliwianie kulturowe małego dziecka.

Na podstawie wyników badań nasuwa się kilka istotnych wniosków:

- Nauczyciele w większości przypadków mają ograniczoną wiedzę na temat uwrażliwiania kulturowego dzieci.

- Głównym wyznacznikiem pracy dydaktyczno-wychowawczej jest program. Nauczyciele organizują zbyt mało zajęć, które miałyby pomóc dzieciom w zrozumieniu kultury osób odmiennych kulturowo z grupy. Powoduje to pogłębianie negatywnych stereotypów, izolację i marginalizację, a przede wszystkim ukierunkowanie myślenia dzieci w sposób spontaniczny, często nieadekwatny do rzeczywistości. 
- Negatywne jest to, że nadal w wielu sytuacjach dominuje kultura większości. Mimo że przedszkola i szkoły publiczne w zamierzeniu mają charakter równościowy i powszechny, nie wszyscy mają takie same prawa (szczególnie mam tutaj na myśli kwestie wyznaniowe - np. dzieci wyznań mniejszościowych nie mają zajęć religii w przedszkolu).

Nauczyciele mają bardzo trudne zadania, jakie niesie praca w warunkach wielokulturowości - jak wychowywać, uczyć szacunku i tolerancji do odmienności, uwrażliwiając jednocześnie dzieci na kulturę i wartości rodzime?

Wszystko jednak zależy od nich samych - od podejścia do drugiego człowieka, ale także świadomości i zrozumienia, jak ważne jest uwrażliwianie kulturowe dzieci - wskazywanie różnic, ale nade wszystko podobieństw pomiędzy ludźmi już na etapie wychowania przedszkolnego i edukacji wczesnoszkolnej.

Wnioski z badań jednoznacznie wskazują na potrzebę solidnego przygotowania nauczycieli do podejmowania działań z zakresu edukacji wielo- i międzykulturowej. Zdecydowanie więcej powinno się realizować na studiach pedagogicznych takich przedmiotów jak: edukacja wielo- i międzykulturowa, komunikacja międzykulturowa czy metodyka edukacji międzykulturowej. Celem takich zajęć byłoby nie tylko uwrażliwanie młodych pedagogów na różnice kulturowe, ale także przygotowanie ich do pracy w warunkach wielokulturowości.

Kompetencje do komunikacji międzykulturowej są bardzo ważne, ale nie mniej istotne są wiedza, rzetelne wykształcenie oraz obraz własnego „JA”, który, zdaniem A. Szczurek-Boruty, „może być pierwszym krokiem do lepszego zrozumienia osobowościowych uwarunkowań pracy nauczyciela w warunkach wielokulturowości"31.

Zmieniająca się rzeczywistość społeczna rodzi nowe wyzwania edukacyjne i dyskusje. Niewątpliwie wielokulturowość w grupie przedszkolnej bądź klasie szkolnej w małej placówce wiejskiej jeszcze długo będzie budziła obawy i wątpliwości nauczycieli, rodziców, ale też całej lokalnej społeczności. Ludzie od zawsze różnili się, jednak dominowała kultura większości. Współcześnie warto zwrócić się ku Innym w sposób bardziej przychylny, pokazać drogę wspólnego kompromisu i dialogu.

31 A. Szczurek-Boruta: Obraz własnej osoby a gotowość zawodowa nauczyciela. W: T. Lewowicki, E. Ogrodzka-Mazur, A. Szczurek-Boruta: Praca nauczyciela w warunkach wielokulturowości. Cieszyn - Warszawa - Toruń 2008, Wydział Etnologii i Nauk o Edukacji Uniwersytetu Śląskiego, Wyższa Szkoła Pedagogiczna ZNP w Warszawie, Wydawnictwo Adam Marszałek, s. 56. 
To właśnie przedszkole i szkoła powinny być tymi miejscami, w których dziecko nauczy się współpracować z drugim człowiekiem bez uprzedzeń i stereotypów.

Dzięki dostępności atrakcyjnych środków dydaktycznych i bogatej literatury nauczyciele mają bardzo duże możliwości. Ważne jest też to, aby w praktyce wychowywali dzieci do życia w społeczeństwie - stwarzali możliwości do nabywania umiejętności społecznych, takich jak: współpraca, współdziałanie, pokazywali, czym jest szacunek i tolerancja, a przede wszystkim podejmowali praktyczne działania w zakresie edukacji wielo- i międzykulturowej oraz uwrażliwiali na potrzeby drugiego człowieka.

\section{Bibliografia}

Bachtin M.: Problemy literatury i estetyki. Warszawa 1992, Czytelnik.

Badania CBOS: Co się zmienito w stylu życia Polaków w ostatnim dwudziestoleciu? Warszawa 2009.

Bandura A.: Teoria społecznego uczenia się. Warszawa 2007, PWN.

Birch A.: Psychologia rozwojowa w zarysie. Od niemowlęctwa do dorostości. Warszawa 2012, PWN.

Delors J.: Edukacja. Jest w niej ukryty skarb. Raport dla UNESCO. Warszawa 1998, Stowarzyszenie Oświatowców Polskich.

Dobrowolska B.: Postawy nauczycieli wobec edukacji międzykulturowej a kultura szkoty. Kraków 2015, Oficyna Wydawnicza „Impuls”.

Guzik-Tkacz M.: Badania diagnostyczne w pedagogice $i$ w psychopedagogice.

Warszawa 2011, Wydawnictwo Akademickie „Żak”.

http://cbos.pl/SPISKOM.POL/2009/K_019_09.PDF.

http://www.slaskie.pl/

Łobocki M.: Metody i techniki w badaniach pedagogicznych. Kraków 2011, Oficyna Wydawnicza „Impuls”.

Nikitorowicz J.: Edukacja międzykulturowa. Kreowanie tożsamości dziecka. Gdańsk 2008, GWP

Nikitorowicz J.: Pogranicze. Tożsamość. Edukacja międzykulturowa. Białystok 1995, Wydawnictwo Uniwersyteckie „Trans Humana”.

Nikitorowicz J.: Tolerancja. Idea i cel edukacji międzykulturowej. „Problemy Opiekuńczo-Wychowawcze" 1995, nr 6.

Nikitorowicz J.: Wielokulturowość - wyzwania dla edukacji międzykulturowej.

W: J. Gajda (red.): Edukacja zorientowana na XXI w. Lublin 2000, UMCS. 
Olbrycht K.: Edukacja aksjologiczna - próba interpretacji i zarys programu. W: K. Olbrycht (red.): Edukacja aksjologiczna. T. 1. Katowice 1994, UŚ.

Olbrycht K.: Prawda, dobro, piękno w wychowaniu człowieka. Katowice 2000, UŚ.

Olbrycht K.: Rola ksztatcenia aksjologicznego w działaniach pedagogicznych w spotecznościach wielokulturowych. W: T. Lewowicki, E. Ogrodzka-Mazur, A. Gajdzica (red.): Świat wartości i edukacja międzykulturowa. Cieszyn - Warszawa 2003, UŚ - Filia w Cieszynie, Wyższa Szkoła Pedagogiczna ZNP w Warszawie.

Olbrycht K.: Tolerancja a wychowanie. W: Olbrycht K. (red.): Edukacja aksjologiczna. Katowice 1995, UŚ.

Palka S.: Metodologia. Badania. Praktyka pedagogiczna. Gdańsk 2006, GWP. Palka S.: Triangulacja w badaniach procesu dydaktyczno-wychowawczego. http://repozytorium.ukw.edu.pl

Papugowa W.: Jak wychowujemy? „Bliżej Przedszkola” 2015, nr 11.

Przetacznik-Gierowska M., Makiełło-Jarża G.: Psychologia rozwojowa $i$ wychowawcza wieku dziecięcego. Warszawa 1992, WSiP.

Radwiłowiczowie M. R.: Nauczyciel klas poczatkowych. Warszawa1981, WSiP.

Rozporzadzenie Ministra Edukacji Narodowej z dnia 27sierpnia 2012 r. w sprawie podstawy programowej wychowania przedszkolnego oraz ksztatcenia w poszczególnych typach szkót. http://isap.sejm.gov.pl

Rubacha K.: Metodologia badań nad edukacja. Warszawa 2008, WAiP.

Schaffer R.: Psychologia dziecka. Warszawa 2014, PWN.

Szczurek-Boruta A.: Doświadczenia społeczne w przygotowaniu przyszłych nauczycieli do pracy warunkach wielokulturowości. Torun 2013, Wydawnictwo Adam Marszałek.

Szczurek-Boruta A.: O przygotowaniu nauczycieli do pracy w warunkach wielokulturowości - konteksty, opinie studentów, propozycje. Toruń 2014, Wydawnictwo Adam Marszałek.

Szczurek-Boruta A.: Obraz własnej osoby a gotowość zawodowa nauczyciela. W: T. Lewowicki, E. Ogrodzka-Mazur, A. Szczurek-Boruta: Praca nauczyciela w warunkach wielokulturowości. Cieszyn - Warszawa - Toruń 2008, Wydział Etnologii i Nauk o Edukacji Uniwersytetu Śląskiego, Wyższa Szkoła Pedagogiczna ZNP w Warszawie, Wydawnictwo Adam Marszałek. Szczurek-Boruta A.: Tożsamość i jej szerszy kontekst instytucjonalny - o przydatności teorii strukturalizacji Anthony'ego Giddensa dla teorii i praktyki edukacji międzykulturowej. W: T. Lewowicki, A. Szczurek-Boruta, 
E. Ogrodzka-Mazur: Teorie i modele badań międzykulturowych. Cieszyn

- Warszawa 2006, UŚ, Wyższa Szkoła Pedagogiczna ZNP w Warszawie. Tillmann K.J.: Teorie socjalizacji. Spoteczność, instytucja, upodmiotowienie, Warszawa 1996, PWN.

Witkowski L.: Uniwersalizm pogranicza: o semiotyce kultury Michaiła Bachtina w kontekście edukacji. Toruń 1991, Wydawnictwo Adam Marszałek.

\section{Cultural sensitization of children in educational practice}

\section{Summary}

In the article, the need of cultural sensitization of children is indicated as an important aspect of socialization and education as well as the role of the teacher in this process is shown. The results are presented of my own research conducted among children in preschool age and teachers of pre- and early school education according to Jerzy Nikitorowicz's concept of cultural sensitization and Albert Bandura's theory of social education.

In the analysis, an attempt is also made to answer the question why it is worth sensitizing children to cultural differences that occur among people starting from the pre- and early school age as well as the benefits that result from this activity are presented.

Key words : teacher, child, cultural sensitization, multiculturalism, intercultural education 